\title{
Durability Properties of Self-Compacting Concrete (SCC) Incorporating Cassava Peel Ash (CPA)
}

\author{
M.T. Abdulwahab ${ }^{1, *}$, O.A.U. Uche ${ }^{2}$ \\ ${ }^{1,2}$ Department of Civil Engineering, Bayero University Kano, Kano, NIGERIA.
}

\begin{abstract}
Self-compacting concrete (SCC) is a highly flowable concrete with enhanced strength and surface finish. The production of SCC requires high content of Portland cement (PC), which in turn consumes a lot of energy and emits greenhouse gases like $\mathrm{CO}_{2}$ and $\mathrm{CH}_{4}$ to the atmosphere during its production. Also, environmental pollution arising from agricultural wastes such as cassava peels, groundnut shells, is a cause of concern. Cassava processing centres alone generate approximately 40 million tons of wastes per annum in Nigeria, while attempts to eliminate them through burning or natural decomposition is sometimes unsuccessful. It is important to reduce the $\mathrm{CO}_{2}$ emission during the production of $\mathrm{PC}$ and environmental pollution caused by cassava peels through partial replacement of cement in the SCC. This study assesses the durability properties of SCC produced with cassava peel ash $(\mathrm{CPA})$ at $5 \%, 10 \%, 15 \%, 20 \%$ and $25 \%$ replacement level of cement. The effects of water absorption, acid $\left(\mathrm{H}_{2} \mathrm{SO}_{4}\right)$ and salt $\left(\mathrm{MgSO}_{4}\right)$ attack and elevated temperature were investigated on the CPA-SCC specimens. It was revealed that the CPA improves the resistance to $\mathrm{H}_{2} \mathrm{SO}_{4}$ and $\mathrm{MgSO}_{4}$ degradation while the performance is poor when subjected to elevated temperature compared to the control specimen. Also, an optimum of 5\% cement replacement is recommended for grade 35 compressive strength of CPA-SCC. However, the rate of water absorption reduced to a minimum when CPA is used in SCC as a result of an improved pore structure of the CPA-SCC specimen.
\end{abstract}

Keywords: Ordinary Portland Cement, Self-Compacting Concrete, Cassava Peel Ash, Durability, Super-plasticizer

\subsection{INTRODUCTION}

There is no doubt that concrete is of exceptional significance in structures and constructions at large. It is a composite material made of fine and coarse aggregate bonded together with cement and addition of water in accurate proportion. As indicated by CSI [1], the utilization of concrete is expected to be equal to 25 billion tons per year which implies above 3.8 tons per individual per year in the world.

Since it was introduced for the first time in the early nineties [2], Self-Compacting Concrete (SCC) has become one of the most desirable types of concrete, and it has opened a new area of research in the field of concrete technology. SCC as explained by Heba [3] is a concrete which can be placed and compacted under its own weight with little or no vibration, and which is at the same time cohesive enough to be handled without segregation or bleeding of the fresh concrete. Among the benefits of SCC are easier placing, faster casting and better finishing with less efforts. SCC relies on very high contents of binder (cement) and the addition of super-plasticizers for better workability.

However, the high consumption of energy and emission of the carbon dioxide $\left(\mathrm{CO}_{2}\right)$ to the atmosphere

*Corresponding author (Tel: +234 (0) 806649 6979)

Email addresses: amtaytechnology@yahoo.com (M.T. Abdulwahab), okoauche@yahoo.co.uk (O.A.U. Uche) during the manufacturing process of cement is a great cause of concern [4]. It was reported by Malhotra [5] that the amount of the $\left(\mathrm{CO}_{2}\right)$ released during the manufacture of cement due to the calcination of limestone and combustion of fossil fuel is in the order of one ton for every ton of cement produced. Therefore, the use of novel and sustainable concrete with low cement content becomes a very attractive approach to reduce this concern.

Cassava (Manihot esculenta) is a root and tuber crop grown in all ecological zones of Nigeria, but most predominantly in the southern parts and middle belt of the country [6]. As reported by Adesanya et al. [7], the cassava peel constitutes between $20-35 \%$ of the weight of tuber, especially in the case of hand peeling. The Cassava Peel Ash (CPA) is one of the agricultural wastes which is a by-product of the combustion of refuse generated during cassava processing and has been found to be pozzolanic when it is calcined at $700^{\circ} \mathrm{C}$ for 90 minutes as reported by Salau and Olonade [8].

The availability in large quantities of the wastes of cassava peels around garri processing centres is a cause of concern. These wastes create environmental pollution as attempts to eliminate them through burning or natural decomposition is sometimes unsuccessful. Hence, recycling of such waste into new building materials could be a viable solution to the environmental pollution problem. 
This study aims to investigate the durability properties of self-compacting concrete made with CPA. This was achieved by characterizing the CPA for use in SCC and evaluating its durability characteristics with regards to various proportions of substitution of cement at different curing age.

\subsection{MATERIALS AND METHODS \\ 2.1 Materials}

Ordinary Portland Cement of grade 42.5R, which conforms with the recommendation of BS EN 197 [9] and specific gravity tested to be 3.16 as presented in Table 1 was used for this study as the main binder, while cassava peel ash with specific gravity of 2.01 was used as the alternative cementitious binder.

The cassava peels were collected from different cassava farmers' dump site at Dadin-Duniya Village, Gabasawa Local Government Area, Kano-Nigeria. They were collected in bags of $50 \mathrm{~kg}$, cleaned and then air-dried for 48 hours to get rid of moisture. They were then subjected to controlled burning a temperature of $600^{\circ} \mathrm{C}$ for about two (2) hours at the Ceramic Section of Industrial Design Department of School of Technology, Kano State Polytechnic, Kano-Nigeria. The ash was allowed to cool and then sieved using a $75 \mu \mathrm{m}$ B.S. sieve so as to produce a fine ash. It was checked for its suitability as pozzolana in accordance with ASTM C618 [10].

Table 1 depicts the chemical composition of cement and CPA as determined by X-Ray Fluorescence (XRF) analysis using analytical method at Spectra Laboratory Services, Kaduna-Nigeria.

The fine aggregate used is clean river sand collected from River Challawa, Kano-Nigeria, with a specific gravity of 2.62. Sieve analysis of the fine aggregate as shown in Figure 1 was conducted in accordance with BS EN 933 [11] in order to determine the particle size distribution as well as grading limits based on BS EN 882 [12] and was classified as Zone 2 fine aggregates.

Table 1: Chemical composition of OPC and CPA

\begin{tabular}{|c|c|c|c|c|}
\hline Oxide & $\begin{array}{l}\text { Dangote } \\
\text { Cement }(\%)\end{array}$ & $\begin{array}{l}\text { BS EN 197-1 } \\
\text { (2000) Recommendation }\end{array}$ & CPA (\%) & $\begin{array}{l}\text { ASTM C618 } \\
\text { Recommendation }\end{array}$ \\
\hline $\mathrm{SiO}_{2}$ & 15.614 & $\mathrm{CaO}+\mathrm{SiO}_{2} \geq 50 \%$ & 43.164 & $\mathrm{SiO}_{2}+\mathrm{Al}_{2} \mathrm{O}_{3}+\mathrm{Fe}_{2} \mathrm{O}_{3} \geq 70 \%$ \\
\hline $\mathrm{Al}_{2} \mathrm{O}_{3}$ & 3.222 & & 3.945 & \\
\hline $\mathrm{Fe}_{2} \mathrm{O}_{3}$ & 3.343 & $\mathrm{CaO} / \mathrm{SiO} \geq 2 \%$ & 3.320 & $L o I \leq 12 \%$ \\
\hline $\mathrm{CaO}$ & 74.088 & & 21.090 & \\
\hline MgO & 0 & $S O_{2}<35 \%$ & 3.395 & \\
\hline $\mathrm{CuO}$ & 0.003 & & 0.003 & \\
\hline MnO & 0.045 & $M a O<5.0 \%$ & 0.056 & \\
\hline $\mathrm{Cr}_{2} \mathrm{O}_{3}$ & 0 & & 0.005 & \\
\hline $\mathrm{TiO}_{2}$ & 0.058 & $C l \leq 0.1 \%$ & 0.475 & \\
\hline $\mathrm{ZnO}$ & 0.004 & & 0.055 & \\
\hline $\begin{array}{l}\text { Loss of } \\
\text { ignition }\end{array}$ & 3.13 & $L o I \leq 5 \%$ & 15.27 & \\
\hline $\begin{array}{l}\text { Specific } \\
\text { gravity }\end{array}$ & 3.16 & & 2.01 & \\
\hline
\end{tabular}

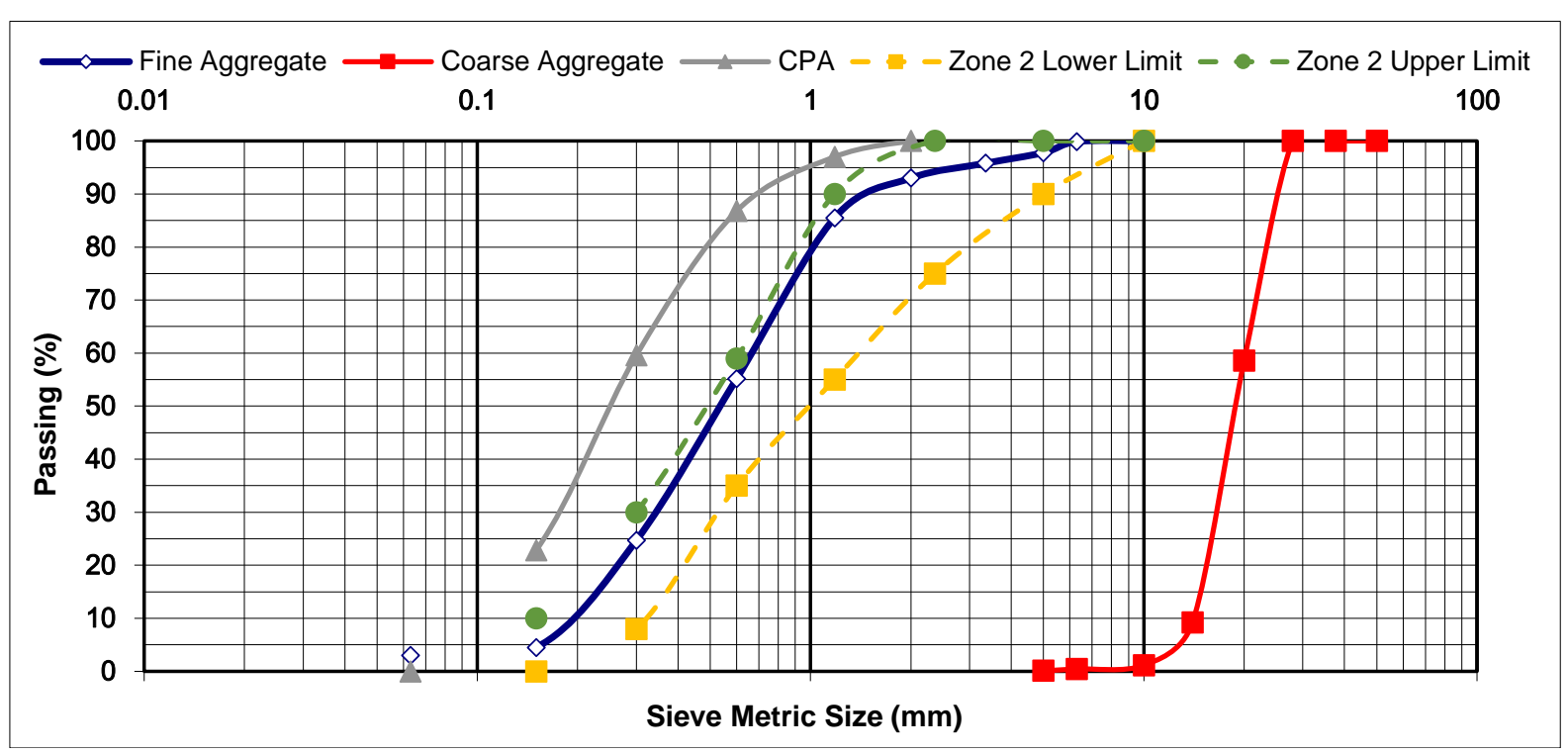

Figure 1: Particle size distribution chart of CPA, fine and coarse aggregates 
Also, crushed granite of $20 \mathrm{~mm}$ nominal diameter with aggregates crushing value of $22 \%$ and specific gravity of 2.7 was used as the coarse aggregates. While the water used for mixing and curing of the SCC is potable tap water, which satisfied ASTM C1602-12 [13] specification of water for use in concrete mixtures, the super-plasticizer used is a Conplast SP432-MS, which is a chloride free, super-plasticizing admixture based on selected sulphonated naphthalene polymers. It is a brown solution which instantly disperses in water. It was used in conformity to BS EN 934-2 [14] and ASTM C494 [15] type B, D and G, depending on the dosage used. It has a specific gravity of 1.19 as specified by the manufacturer.

\subsection{Sample preparation and testing}

The mix design for SCC with strength grade 35 was carried out in accordance with ACI 211.1-91 [16] and EFNARC [17] specification and guidelines for SCC and the final mix proportions for various CPA contents are presented in Table 2. Also, superplasticizer dosage of 1.4 $\%$ of weight of binder was used.

Table 2: SCC mix proportion per cubic meter

\begin{tabular}{|c|c|c|c|c|c|c|c|}
\hline $\begin{array}{l}\text { Mix } \\
\text { No. }\end{array}$ & $\begin{array}{l}\text { CPA } \\
(\%)\end{array}$ & $\begin{array}{c}\text { Cement } \\
(\mathrm{kg})\end{array}$ & CPA (kg) & $\begin{array}{c}\text { Fine } \\
\text { Aggregates } \\
(\mathbf{k g}) \\
\end{array}$ & $\begin{array}{c}\text { Coarse } \\
\text { Aggregates } \\
(\mathrm{kg}) \\
\end{array}$ & Water (kg) & $\begin{array}{c}\text { Super- } \\
\text { plasticizer } \\
(\mathrm{kg}) \\
\end{array}$ \\
\hline MC-00 & 0 & 475.00 & 0.00 & 804.07 & 885.93 & 190.00 & 6.65 \\
\hline MC-01 & 5 & 451.25 & 23.75 & 804.07 & 885.93 & 190.00 & 6.65 \\
\hline MC-02 & 10 & 427.5 & 47.50 & 804.07 & 885.93 & 190.00 & 6.65 \\
\hline MC-03 & 15 & 403.75 & 71.25 & 804.07 & 885.93 & 190.00 & 6.65 \\
\hline MC-04 & 20 & 380.00 & 95.00 & 804.07 & 885.93 & 190.00 & 6.65 \\
\hline MC-05 & 25 & 356.25 & 118.75 & 804.07 & 885.93 & 190.00 & 6.65 \\
\hline
\end{tabular}

Reference to the SCC mix proportion, a total of ninety (90) specimens were produced for compressive strength test. A dry mix of cement and CPA were thoroughly done and added to fine aggregate, which was then mixed together with the coarse aggregate. Mixing was done manually and cast in steel cylindrical moulds of $100 \mathrm{~mm}$ diameter and $200 \mathrm{~mm}$ length and then cured in water for 3, 7, and 28 days respectively in accordance with BS EN 12390-2 [18].

\subsubsection{Water absorption of CPA SCC}

The water absorption test was conducted in accordance with BS EN 1881-122 [19] on a total of eighteen (18) $100 \mathrm{~mm} \times 100 \mathrm{~mm}$ x $100 \mathrm{~mm}$ cubes produced at $0,5,10,15,20$ and $25 \%$ cement replacement with CPA and then cured in water for 28 days. The specimens were air-dried for 24 hours, weighed and the weight recorded. They were further cured for 7 days in water, air-dried and re-weighed to determine the amount of water absorbed using Equation 1.

Water absorption $=\frac{\mathrm{W}_{2}-\mathrm{W}_{1}}{\mathrm{~W}_{1}} \times 100(\%)$

Where:

$\mathrm{W}_{1}=$ weight of dried cube $(\mathrm{g})$

$\mathrm{W}_{2}=$ weight of saturated cube $(\mathrm{g})$

\subsubsection{Effect of acid and salt on CPA SCC}

A solution of Hydrogen Tetraoxosulphate (VI) acid $\left(\mathrm{H}_{2} \mathrm{SO}_{4}\right)$ of $5 \%$ concentration was prepared in a container and eighteen (18) concrete cylinders of $100 \mathrm{~mm}$ diameter and $200 \mathrm{~mm}$ height after curing in water for 28 days were weighed and then immersed in the acidic solution. The specimens were further cured for 3, 7 and 28 days respectively in the solution. At the lapse of the curing periods, the specimens were air dried and reweighed to determine the weight loss of SCC containing CPA subjected to the acidic aggression using Equation 2.

The procedure was repeated to test for the effect of salt but with a solution of Magnesium Tetraoxosulphate (V) $\left(\mathrm{MgSO}_{4}\right)$ of $5 \%$ concentration.

Percentage weight loss $=\frac{\text { Loss in weight }}{\text { Initial weight }} \times 100 \%$

\subsubsection{Effect of Heat on CPA SCC}

Hardened CPA SCC cubes of $100 \mathrm{~mm} \times 100 \mathrm{~mm}$ $\mathrm{x} 100 \mathrm{~mm}$ after curing for 28 days in water, were weighed and then subjected to elevated heat for one (1) hour using Carbolite CWF1100 model furnace at a temperature range of $0{ }^{\circ} \mathrm{C}$ to $1000{ }^{\circ} \mathrm{C}$ at $200{ }^{\circ} \mathrm{C}$ interval and then allowed to cool. The effect of the elevated temperature was evaluated using Equation 3 after being reweighed. 
Percentage weight loss $=\frac{\mathrm{W}_{1}-\mathrm{W}_{2}}{\mathrm{~W}_{1}} \times 100(\%)$

Where: $\mathrm{W}_{1}=$ Initial weight $(\mathrm{g}) ; \mathrm{W}_{2}=$ Final weight $(\mathrm{g})$

\subsection{RESULTS AND DISCUSSION}

3.1 Mechanical behaviour

The results of the compressive strength obtained from different CPA SCC mixes used for this study is shown in Figure 2. The strength increases with the age of curing at both 3,7 and 28 days curing while it decreases with increase in the CPA contents. Also, it was recorded that the compressive strength at 28 days is slightly above the design strength of grade 35 when mix MC-01 was used. This increase in strength with age of curing could be ascribed to the pozzolanic reaction between $\mathrm{Ca}(\mathrm{OH})_{2}$ from cement hydration with the $\mathrm{SiO}_{2}$ of CPA. This is also comparable to the report made by Raheem et al. [20] that CPA has the potential to contribute to 28-days strength development when $5 \%$ is used.

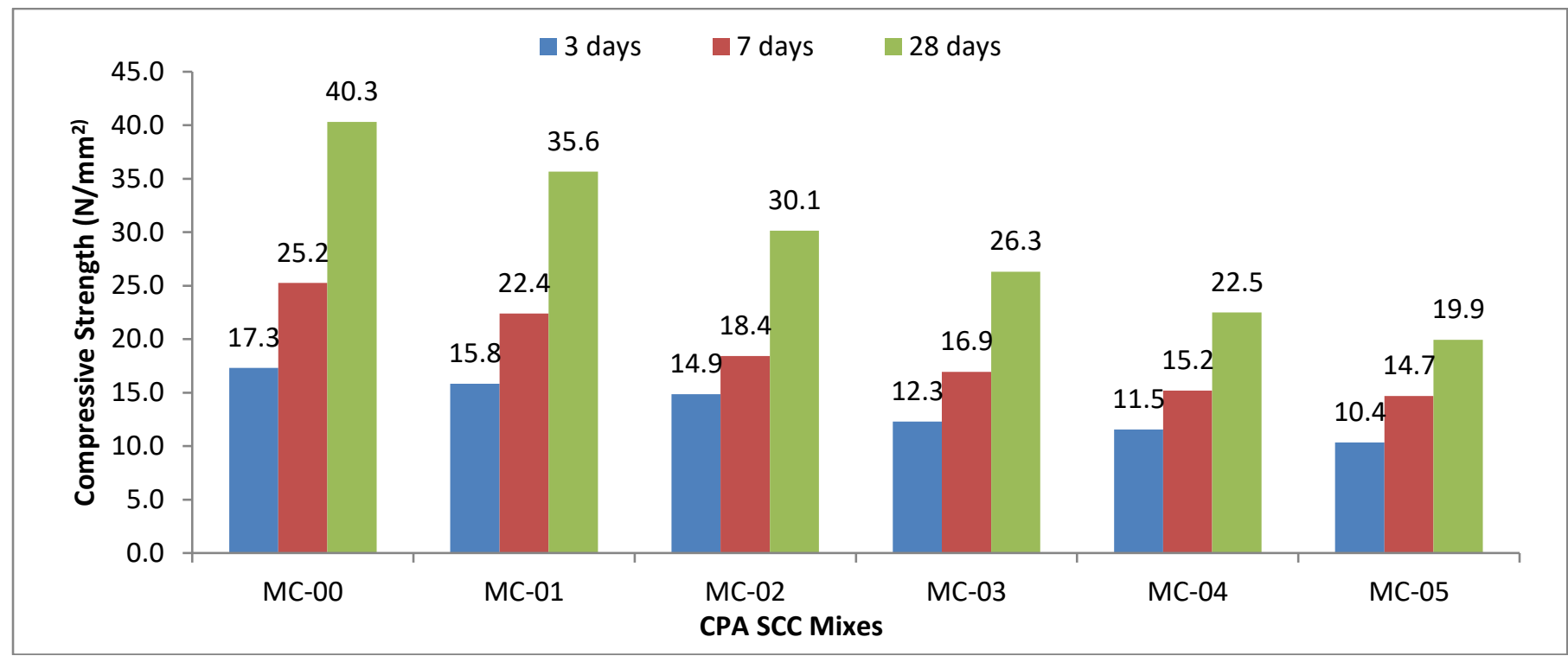

Figure 2: Compressive cylindrical strength of CPA SCC

\subsection{Water absorption}

The water absorption capacity of CPA SCC as presented in Figure 3 decreases with increase in the percentage replacement of cement with CPA. This is in similar vein with Raheem et al. [20] studying the effect of CPA in concrete. The decrease in the water absorption could be as a result of compactness of the SCC matrix as the CPA content increases which as well enhances the homogeneity of the SCC.

It is worth noting that the sulphate attack on the CPA SCC reduces below the control with increase in the content of CPA which could be related to the lesser content of $\mathrm{CaO}$ in the CPA particles compared to that of Portland cement [22].

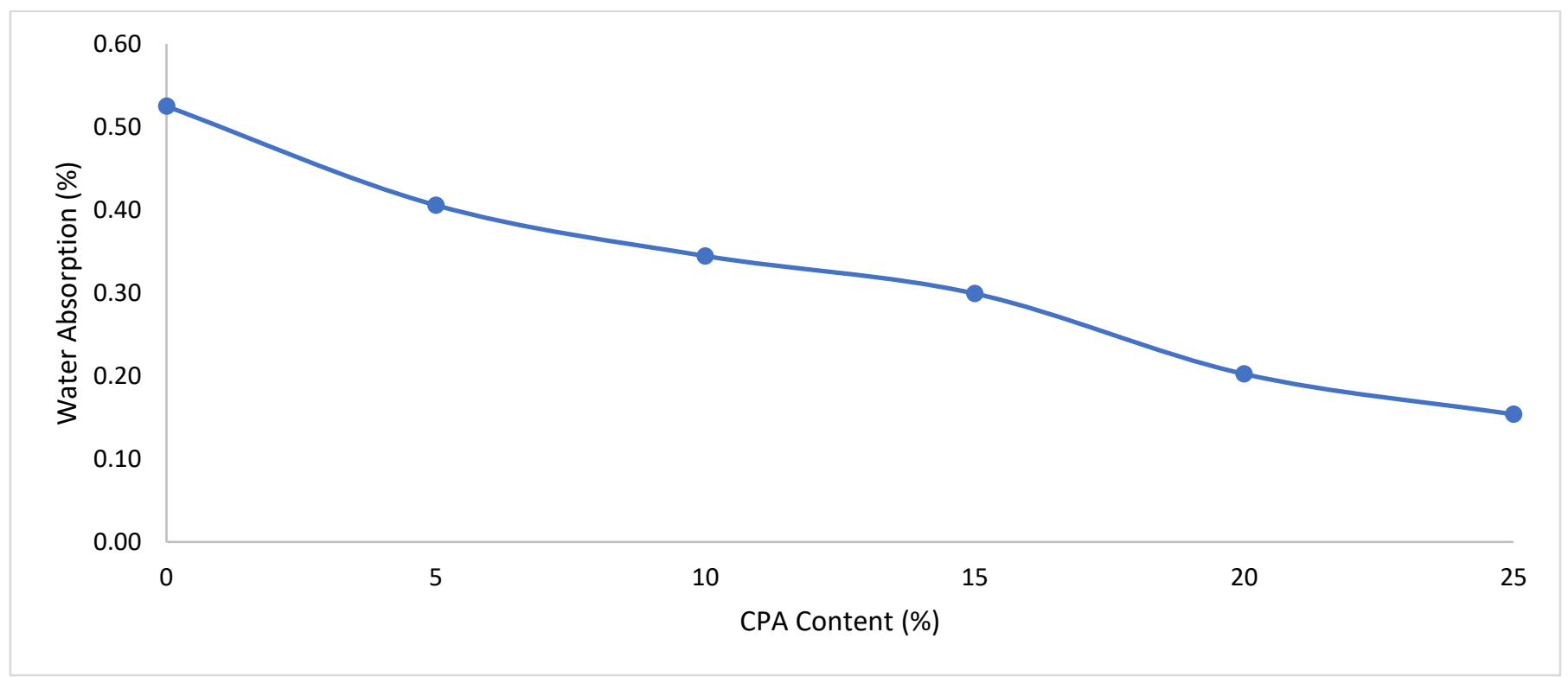

Figure 3: Water absorption for CPA SCC 


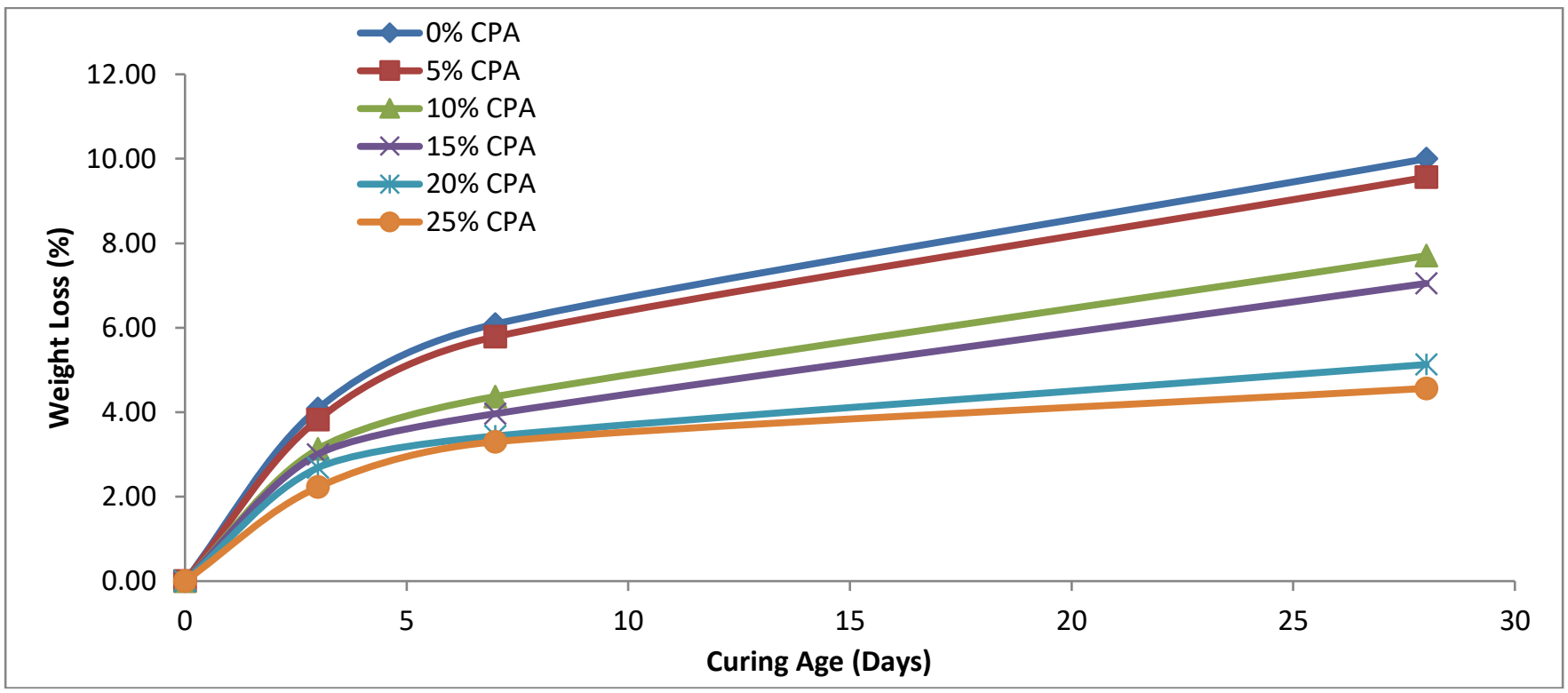

Figure 4: Effect of immersion in $\mathrm{H}_{2} \mathrm{SO}_{4}$ for CPA SCC

\subsection{Immersion in magnesium sulphate $\left(\mathrm{MgSO}_{4}\right)$ salt}

The attack by sulphate on CPA SCC as shown in Figure 5 increases with increase in immersion age which in turn reduces its weight. This could be as a result of continuous sulphate attack with time.
However, the weight loss experienced by the CPA SCC improved with increase in the CPA content. This enhancement could be traced to the pozzolanic reaction and ability of the CPA to fill empty voids in the CPA SCC.

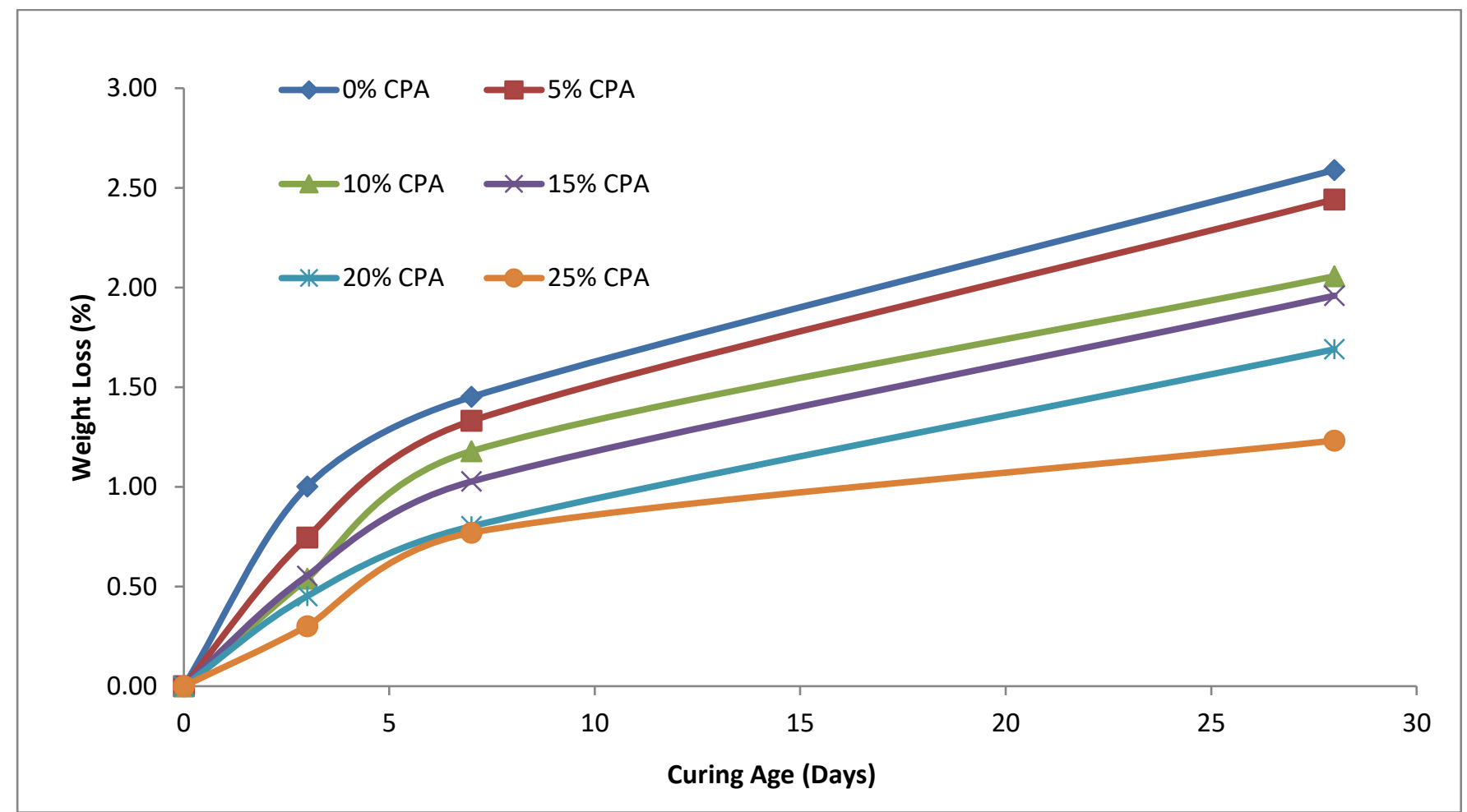

Figure 5: Effect of immersion in $\mathrm{MgSO}_{4}$ for CPA SCC

\section{5}

\section{Effects of elevated temperature on weight loss}

The effect of elevated temperature on CPA SCC as presented in Figure 6 shows that CPA SCC losses weight as the temperature rises as well as the CPA content increases. This could occur as a result of dehydration of hydrated calcium silicate which in turn increases the internal stresses leading to micro cracks on the specimens [23].

The loss in weight could also be attributed to the expulsion of the excess pore water in the CPA SCC as explained by Ogork and Auwal [24]. However, the CPA SCC changes colour from grey to slightly yellowish grey with increase in temperature from $600^{\circ} \mathrm{C}$ and above. 


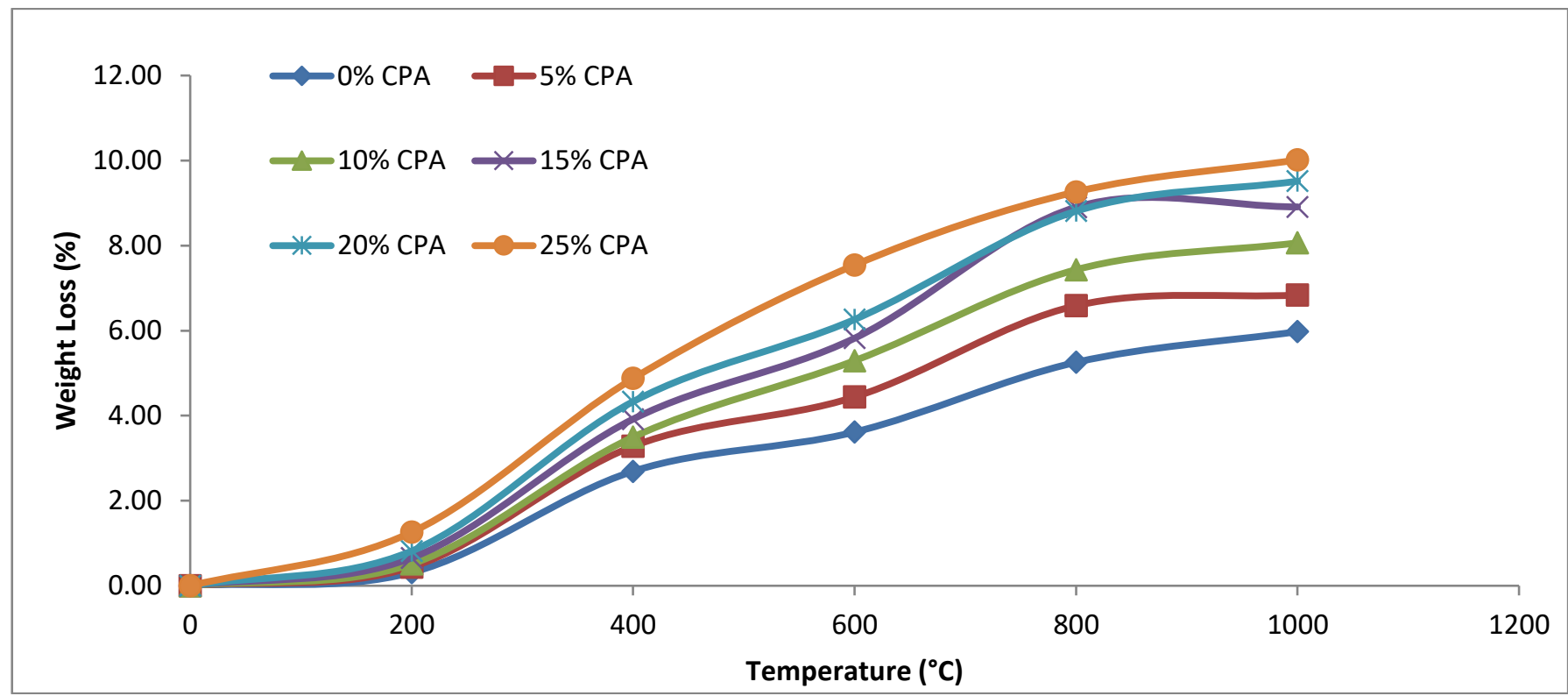

Figure 6: Effect of elevated temperature on weight loss of CPA SCC

\subsection{CONCLUSIONS}

From the study, the following conclusions were drawn.

1. The compressive strength of CPA SCC declined as the CPA content increased, and 5\% is considered as the optimum dose to achieve grade 35 SCC.

2. The incorporation of CPA in SCC lowers its water absorption rate in the hardened state.

3. When exposed to acidic and sulfate attack, the usage of CPA in SCC helps to decrease weight loss.

4. With the addition of CPA, the performance of SCC in elevated hot conditions worsens.

\section{REFERENCES}

[1] Cement Sustainability Initiative, Cement Sustainability Initiative. Also available at: http://www.wbcsdcement.org/index.php/keyissues/sustainabilitywith - [Accessed: 28-12 2017], 2009.

[2] De Schutter, G. and Audenaert, K. "Report 38: Durability of Self-Compacting Concrete-Stateof-the-Art Report of RILEM Technical Committee 205-DSC". RILEM Publications, 2007.

[3] Mohamed, H.A. "Effect of fly ash and silica fume on compressive strength of self-compacting concrete under different curing conditions." Ain Shams Engineering Journal, 2(2), (2011), 79-86.

[4] Kong, D.L.Y. and Sanjayan, J.G. "Damage behavior of geopolymer composites exposed to elevated temperatures." Cement and Concrete Composites, 30(10), (2008), 986-991.
[5] Malhotra, V. M. "Introduction: sustainable development and concrete technology." Concrete International, 24(7), (2002).

[6] Odeyemi, S.O., Atoyebi, O.D. and Ayo, E.K. "Effect of Guinea Corn Husk Ash on the Mechanical Properties of Lateritic Concrete." IOP Conference Series: Earth and Environmental Science, 445(1), (2007).

[7] Adesanya, O.A., Oluyemi, K.A., Josiah, S.J., Adesanya, R., Shittu, L., Ofusori, D., Bankole, M. and Babalola, G. "Ethanol production by Saccharomyces cerevisiae from cassava peel hydrolysate." The Internet Journal of Microbiology, 5(1), (2008), 25-35.

[8] Salau, M.A. and Olonade, K.A. "Pozzolanic Potentials of Cassava Peel Ash". Journal of Engineering Research, 16(1), (2011),10-21.

[9] BS EN 197, "Part 1, Composition, Specification and Conformity Criteria for Common Cements". British Standard Institution, London, 2000.

[10] ASTM C 618, "Specification for Coal Fly Ash and Raw or Calcined Natural Pozzolanas for Use as Mineral Admixtures in Ordinary Portland Cement Concrete" West Conshohocken, U.S.A, 2008.

[11] British Standard Institution, "Test for geometrical properties of aggregates", BS EN 933 - 1 determination of particle size distribution (sieving method), London, BSI, 1997.

[12] BS EN 882, "Specification for Natural Aggregates from Natural Sources". British Standard Institute, London, 1992.

[13] ASTM C1602-12, "Standard Specification for Mixing Water used in the Production Hydraulic Cement Concrete", ASTM International, West Conshohocken, PA, 2012, www.astm.org, 2012. 
[14] British Standard Institution, "Admixtures for Concrete, Mortar and Grout," BS EN 934 - 2 Concrete Admixtures - Definition, Requirements, Conformity, Marking and Labelling, London, BSI, 2012.

[15] ASTM C494, "Standard Specification for Chemical Admixtures for Concrete", ASTM International, West Conshohocken, PA, 2019, www.astm.org, 2019.

[16] ACI 211.1-91, "Standard Practice for Selecting Proportions for Normal, Heavyweight, and Mass Concrete", 2002.

[17] European Federation of National Associations Representing for Concrete EFNARC, "the European Guidelines for Self-Compacting Concrete Specification, Production and Use". EFNARC, UK (www.efnarc.org). 1-63, 2005.

[18] British Standard Institution, "Testing Hardened Concrete - Part 2", BS EN 12390 - 2 - Making and Curing Specimens for Strength Tests, London, BSI, 2019.

[19] British Standard Institution, "Testing Concrete", BS EN 1881 - 122 - Method for Determination of Water Absorption, London, BSI, 2020.

[20] Raheem, S.B., Arubike, E.D. and Awogboro, O.S. "Effects of cassava peel ash (CPA) as alternative binder in concrete." International Journal of Constructive Research in Civil Engineering, 1(2), (2020), 27-32.

[21] Olonade, K.A., Olajumoke, A.M., Omotosho, A.O. and Oyekunle, F.A. "Effects of sulphuric acid on the compressive strength of blended cement-cassava peel ash concrete." Construction Materials and Structures. IOS Press, (2014), 764771.

[22] Chatveera, B. and Lertwattanaruk, P. "Durability of conventional concretes containing black rice husk ash." Journal of environmental management, 92(1), (2011), 59-66.

[23] Othuman Mydin, M.A. and Wang, Y.C. "Thermal and mechanical properties of lightweight foamed concrete at elevated temperatures." Magazine of Concrete Research, 64(3), (2012), 213-224.

[24] Ogork, E.N. and Auwal, A.M. "Durability Characteristics of Self-Compacting Concrete Incorporating Corn Cob Ash". CARD International Journal of Engineering and Emerging Scientific Discovery, 2(1), (2017), 29 41. 